\title{
Effects of the Double-Cutting Method for Ratooning Rice in the SALIBU System under Different Soil Moisture Conditions on Grain Yield and Regeneration Rate
}

\author{
Shutaro Shiraki ${ }^{1, *(\mathbb{D}}$, Thin Mar Cho ${ }^{2}$, Khin Mar Htay ${ }^{2}$ and Kazumi Yamaoka ${ }^{1}$ \\ 1 Rural Development Division, Japan International Research Center for Agricultural Sciences, 1-1 Owashi, \\ Tsukuba, Ibaraki 305-8686, Japan; kyamaoka@affrc.go.jp \\ 2 Department of Agricultural Research, Ministry of Agriculture, Livestock and Irrigation, Myanmar, Yezin, \\ Zeyar Thiri Township, Nay Pyi Taw 15013, Myanmar; tmcho.wurs12@gmail.com (T.M.C.); \\ khinmarhtay2007@gmail.com (K.M.H.) \\ * Correspondence: sshiraki@affrc.go.jp; Tel.: +81-29-838-6686
}

Received: 11 September 2020; Accepted: 21 October 2020; Published: 22 October 2020

\begin{abstract}
In West Sumatra, Indonesia, a high-yield perennial rice cropping method called SALIBU was recently reported, in which the most unique feature is double cutting (DC) at harvest and after harvest. The objective of this study was to verify the ratooning rice yield under the SALIBU system in Myanmar. Two cultivation trials consisting of two cutting and three moisture treatments were conducted in 2019 and 2020. We concluded that double cutting had no positive effect on grain yield and regeneration rate compared with single cutting (SC). For the cutting regime, significant results were detected in the ratoon crops on yield components, but all of these were negative effects of DC, and were statistically lower than those of SC. On the other hand, a significant positive effect of moisture regime on grain yield in all ratoons was observed. The grain yield of the dry regime was significantly increased by $69 \%$ compared with that of the saturated regime. Soil oxidation conditions during the initial growth period of ratoons could contribute to the improved yield performance of the ratoons.
\end{abstract}

Keywords: cutting method; water management; soil oxidation

\section{Introduction}

Ratoon rice cropping is a cultivation technology that has the potential to increase annual rice production per unit land area [1]. Compared with traditional double cropping rice systems, ratoon rice cropping can save labor, time, seed, and water, and requires neither nursery supplies nor land preparation [2]. The labor and seed inputs for ratoon rice cropping were reduced by $29 \%$ and $52 \%$, respectively, compared with double cropping systems [3,4]. However, many studies have concluded that ratoon rice exhibits a low-yield performance, approximately $40-60 \%$ that of the main crop $[5,6]$; thus, low and unstable grain yield has limited the wide adoption of ratoon cropping.

In recent years, in West Sumatra, Indonesia, a perennial rice cropping system called SALIBU, which is named after the Indonesian words "reproduction" and "mother", has been practiced and found to produce a yield equivalent to that of single rice cropping multiple times annually. Ratoon rice cropping, however, has not yet become common in Indonesia. Erdiman et al. [7] reported a main crop yield of 6 ton ha ${ }^{-1}$, while ratoon rice under the SALIBU system harvested six consecutive times yielded 6-7 ton ha ${ }^{-1}$. This is probably because ratoon cropping with the SALIBU system has been performed under ideal cultivation conditions, using suitable varieties and best management practices 
in a desirable climate for rice. However, little research has been conducted on the SALIBU system, and it is important to study this system in order to enhance the productivity of ratoon rice cropping systems.

Considering a common ratoon cropping system, the most unique technology of SALIBU is the double cutting for harvest and ratooning. In the SALIBU system, the cutting height is determined based on a plant height of approximately $15-30 \mathrm{~cm}$ above the ground surface. After 7-10 days of harvesting, residual stubble is recut at a height of $3-5 \mathrm{~cm}$. The additional cutting of residual stubbles is carried out using a mowing machine [8,9]. The double-cutting SALIBU system, which requires additional labor for second cutting, should obtain higher yield than the conventional ratooning system. Otherwise, the SALIBU system will be unacceptable to the farmers.

One study has reported the effect of additional cutting in ratoon rice cropping. Pasaribu et al. [10] conducted a study on yield performance of ratoon rice using the System of Rice Intensification for the main crop and double cutting for the ratoon crop compared with conventional transplanting and ratooning. However, this study did not assess the effect of differences in final cutting height between 5 and $20 \mathrm{~cm}$, so it could not determine whether the yield was affected by additional cutting or cutting height. If there are positive effects of additional cutting on grain yield, as in our hypothesis, the excessive suppression of plant growth by additional cutting might have stimulated the secretion of plant hormones to activate regeneration ability, thereby contributing to the yield performance.

Differences in the cutting height of the main crop are an important factor in the yield performance of ratoons; therefore, many studies have examined the effect of cutting height on grain yield. However, the response of grain yield to cutting height has been inconsistent in previous studies. For example, the application of a cutting height of $0-15 \mathrm{~cm}$ above the soil surface was recommended in few studies [11-14]. A medium cutting height of $20-30 \mathrm{~cm}$ was suggested in some studies [15-19]. A cutting height $\geq 40 \mathrm{~cm}$ was recommended by other studies [20-22].

Moreover, soil moisture conditions before and after the main crop harvesting should be further examined. Most studies on the water management of ratoon have previously focused on the effects of irrigation water depth, period, and timing on grain yield and regeneration ability $[1,16,23-25]$, and most have concluded that withdrawal of water several days before harvest, leaving humid soil, with re-irrigation as ratoon growth progresses, encourages ratoon crop production [26]. These are similar moisture conditions to those found in the SALIBU system reported by $[8,9]$. However, few studies have evaluated the quantity of soil moisture before and after harvest on grain yield. In the SALIBU system, double cutting with a final cutting height of $5 \mathrm{~cm}$ under humid moisture conditions during main crop harvesting might enhance yield performance.

Therefore, this study aimed to examine ratoon cropping in the SALIBU system focused on double cutting under different soil moisture conditions before and after harvest in Myanmar. Few studies on ratoon crop have been conducted in Myanmar. Rice is a vital crop that was grown in $34 \%$ of the country's total cultivated area in 2016 [27]. Rice dominates the agricultural sector, which is the largest and most productive portion of the Myanmar economy. On the one hand, labor shortage in agriculture continues to increase because of the growing industrial sector even though the practice of agriculture depends on human labor force [28]. In Myanmar, sustainable development of rice cropping systems is a crucial issue, and further studies on cropping techniques that can reduce labor force are required.

\section{Materials and Methods}

\subsection{Experimental Field Using Concrete Tanks}

The study sites were located in an experimental field at the Department of Agricultural Research (latitude 19.825, longitude 96.274), Ministry of Agriculture, Livestock and Irrigation, Myanmar, in Zayarthiri Township in the Naypyidaw. The experimental paddy field had 28 concrete tanks measuring $1.8 \mathrm{~m}$ length $\times 0.9 \mathrm{~m}$ width $\times 0.4 \mathrm{~m}$ depth in order to manage soil moisture during before and after harvesting. Soil properties in the tank experiment before trials were as follows: sandy loam soil texture, $1.74 \mathrm{~g} \mathrm{~cm}^{-1}$ dry bulk density, $0.03 \%$ total nitrogen $(\mathrm{N}), 0.01 \%$ total sulfur $(\mathrm{S}), 160 \mathrm{mg} \mathrm{kg}^{-1}$ available $\mathrm{N}$, 
$304 \mathrm{mg} \mathrm{kg}^{-1}$ phosphorus (P), and $185 \mathrm{mg} \mathrm{kg}^{-1}$ potassium (K). The rice cultivar used was "Theehtetyin" (indica), a popular variety in Myanmar with a normal crop duration of 110-115 days. The main crop, consisting of approximately 21-day-old seedlings, was transplanted with $20 \times 20 \mathrm{~cm}$ spacing and a total of 45 plants ( 9 rows $\times 5$ lines) in the tank. A basal level of triple superphosphate fertilizer (18.5 $\mathrm{kg} \mathrm{P} \mathrm{ha}^{-1}$ ) was applied before transplanting for the main crop and 2 weeks before cutting for the ratoon crop. Nitrogenous fertilizer $\left(87 \mathrm{~kg} \mathrm{~N} \mathrm{ha}^{-1}\right)$ and muriate of potash $\left(31 \mathrm{~kg} \mathrm{~K} \mathrm{ha}^{-1}\right)$ were applied equally to each tank at around 7, 30, and 50 days after transplanting and at the flowering stages for the main crop, and the ratoon crop was dosed at around 14, 30, and 50 days after cutting of the main crop and at the flowering stage.

\subsection{Cropping Schedules}

The cultivation trials were timed to avoid harvest during the monsoon season (i.e., between June and September) in order to facilitate the dry soil moisture regime (Table 1). The first trial was initiated from February to August 2019 with double cropping. After harvesting of R1-1 and a randomized plot, the second trial was implemented during September 2019 to May 2020 with triple cropping. The total rainfall of each season was $103 \mathrm{~mm}$ during the summer (i.e., between March to May), $684 \mathrm{~mm}$ during the monsoon, $100 \mathrm{~mm}$ in the postmonsoon (i.e., between October to December), and $0 \mathrm{~mm}$ in winter (i.e., between December to February). The mean solar radiation was $25.4 \mathrm{MJ} \mathrm{m}^{-2} \mathrm{~d}^{-1}$ in the summer, 17.9 $\mathrm{MJ} \mathrm{m}^{-2} \mathrm{~d}^{-1}$ in the monsoon, $19.4 \mathrm{MJ} \mathrm{m}^{-2} \mathrm{~d}^{-1}$ in the postmonsoon, and $17.2 \mathrm{MJ} \mathrm{m}^{-2} \mathrm{~d}^{-1}$ in the winter. The mean daily maximum and minimum temperature were $36{ }^{\circ} \mathrm{C}$ and $23^{\circ} \mathrm{C}$ in the summer, $33{ }^{\circ} \mathrm{C}$ and $25{ }^{\circ} \mathrm{C}$ in the monsoon, $35^{\circ} \mathrm{C}$ and $23^{\circ} \mathrm{C}$ in the postmonsoon, and $32{ }^{\circ} \mathrm{C}$ and $16{ }^{\circ} \mathrm{C}$ in the winter, respectively.

Table 1. Cultivation information for the main crop and ratoon rice.

\begin{tabular}{cccccc}
\hline Cropping & Season & Sowing Date & $\begin{array}{c}\text { Transplanting } \\
\text { Date }\end{array}$ & $\begin{array}{c}\text { Cutting } \\
\text { (Harvesting) } \\
\text { Date }\end{array}$ & $\begin{array}{c}\text { Cultivation } \\
\text { Duration }\end{array}$ \\
\hline Main Crop (MC1) & Summer 2019 & $\begin{array}{c}\text { First Trial in 2019 } \\
\text { 15 February }\end{array}$ & 7 March & 1 June & 106 days \\
Ratoon (R1-1) & Monsoon 2019 & - & - & $\begin{array}{c}21 \text { and 26 } \\
\text { August }\end{array}$ & $81-82$ days \\
\hline Main crop (MC2) & Postmonsoon 2019 & $\begin{array}{c}\text { Second Trial in 2019-2020 } \\
\text { 6 September }\end{array}$ & 25 September & 12 December & 97 days \\
Ratoon (R2-1) & Winter 2019-2020 & - & - & 1 March & $76-80$ days \\
Ratoon (R2-2) & Summer 2020 & - & - & 4 May & $60-64$ days \\
\hline
\end{tabular}

\subsection{Plot Design and Treatments}

For the cutting and soil moisture treatments in the split-plot design, a total of 24 plots ( 2 cutting, 3 moisture, and 4 replications) were prepared. The cutting regime was performed using single cutting (SC) and double cutting (DC). SC was implemented using a cutting height of $5 \mathrm{~cm}$ above the soil surface for harvest, and DC involved a first cutting at a height of $20-40 \mathrm{~cm}$, depending on the crop height for harvest and an additional cutting at a height of $5 \mathrm{~cm} 4$ days after the first cutting.

The soil moisture regimes before and after harvesting were performed under saturated (M1) continuously flooded, humid (M2), and dry (M3) soil moisture conditions. The method of providing moisture regimes for first and second trials differed. For the first trial, we set treatments based on the depth of the water table, and for the second trial, we provided treatments based on reading a tensiometer. In the first trial, we re-irrigated with $25 \mathrm{~L}$ in a tank when water depth below the surface reached $10 \mathrm{~cm}$ for M2 and $20 \mathrm{~cm}$ for M3. In the second trial, M2 was re-irrigated with $25 \mathrm{~L}$ when soil water potential reached $-7 \mathrm{kPa}$, and $\mathrm{M} 3$ was re-irrigated with $25 \mathrm{~L}$ when soil water potential reached $-17 \mathrm{kPa}$. M1 was provided with continuous flooding, with a depth of 2-5 cm water maintained above the soil surface. After the moisture treatment, water management was performed by continuously flooding all plots until around 2 weeks before harvesting. 


\subsection{Data Collection}

We recorded soil water and redox potential in the paddy tank for 2 weeks before and after harvesting at 7:00 AM every morning. Soil water potential was observed using a tensiometer (DIK-3162, Daiki, Japan), which was installed at 10-cm soil depth into two tanks from M2 and M3 of each for the first trials and into all M2 and M3 tanks for the second trials. Redox potential was measured by a portable Eh meter with comparison and platinum electrodes (PRN-41, Fujiwara, Japan) installed at nine points at $3-5 \mathrm{~cm}$ soil depth into the two tanks from each treatment.

We determined the plant growth (i.e., height of plant and number of tillers), number of spikelets per panicle, filled grain weight, 1000-grain weight, weight of dried straw, harvest index, biological yield, and regeneration rate from four adjacent hills, excluding the outer hills in each tank. Grain weight was adjusted to $14 \%$ of the moisture content. The harvest index was equal to filled grains weight/ (weight of dried straw above the stubble + filled and unfilled grains weight). Biological yield $\left(\mathrm{g} \mathrm{m}^{-2}\right)$ was equal to (weight of dried straw and filled grains weight)/area of four hills. Grain yield $\left(\mathrm{g} \mathrm{m}^{-2}\right)$ and number of panicles $\left(\mathrm{m}^{-2}\right)$ were determined from 21 harvested hills ( 3 lines $\times 7$ rows). The plant growth was observed every week after final stem cutting. The regeneration rate was defined as the ratio calculated by the plant growth of the ratoon divided by that of the previous crop $[29,30]$. The harvesting day at the physiological maturity stage was determined about 25 days after the flowering day.

\subsection{Statistical Analysis}

An analysis of variance (ANOVA) and multiple comparisons were performed in R software (version 3.6.0). A two-way ANOVA was performed to find significant differences between treatments with respect to values of the initial and final regeneration rate, grain yield, and yield components in each ratoon crop. The initial regeneration rate represents an average rate at 7, 14, and 21 days after harvest, and final regeneration rate indicates the final rate before harvest. The effects of cutting regime (SC and DC), moisture regime (M1, M2 and M3), and cutting $\times$ moisture interaction were assessed by the ANOVA. When we found significant results using the ANOVA, Tukey's honestly significant difference (HSD) test (0.05 significant difference) for multiple comparisons was used to compare differences between mean values of collected data of each crop to determine which crop's means were different.

\section{Results}

\subsection{Soil Moisture Regimes}

Moisture treatments were initiated after the tank was drained at around 2 weeks before harvesting and were managed until 2 weeks after harvesting. In R1-1, we could not provide moisture regime M3, dry conditions (Figure 1a), because it was difficult to adjust the water table in the tanks, so the moisture regime for R1-1 was defined as M1, M1.5, and M2 based on the observed water potential values. M1.5 was between the saturated (M1) and humid (M2) moisture levels.

After harvesting of the main crop for soil water potential, in R1-1, the mean values of M1.5 and M2 were -5 and $-12 \mathrm{kPa}$, respectively. In R2-1 and R2-2, which showed similar results, the mean values of M2 and M3 for the ratoon crops were -11 and $-19 \mathrm{kPa}$, respectively (Figure 1a). For redox potential, in R1-1, mean values of M1 and M3 were almost constant at approximately -200 and $550 \mathrm{mV}$, respectively, and mean values of M1.5 were $-130 \mathrm{mV}$ after harvesting. The mean values of M2 varied widely from approximately -100 to $400 \mathrm{mV}$ (Figure 1b).

Summarizing for the potential values of each regime, the soil water potentials of the M1, M1.5, M2, and M3 regimes were approximately $0,-5,-11$, and $-19 \mathrm{kPa}$, respectively, and the soil redox potentials of M1, M1.5, M2, and M3 were $-200,-100,200$, and $550 \mathrm{mV}$, respectively. 
(a)

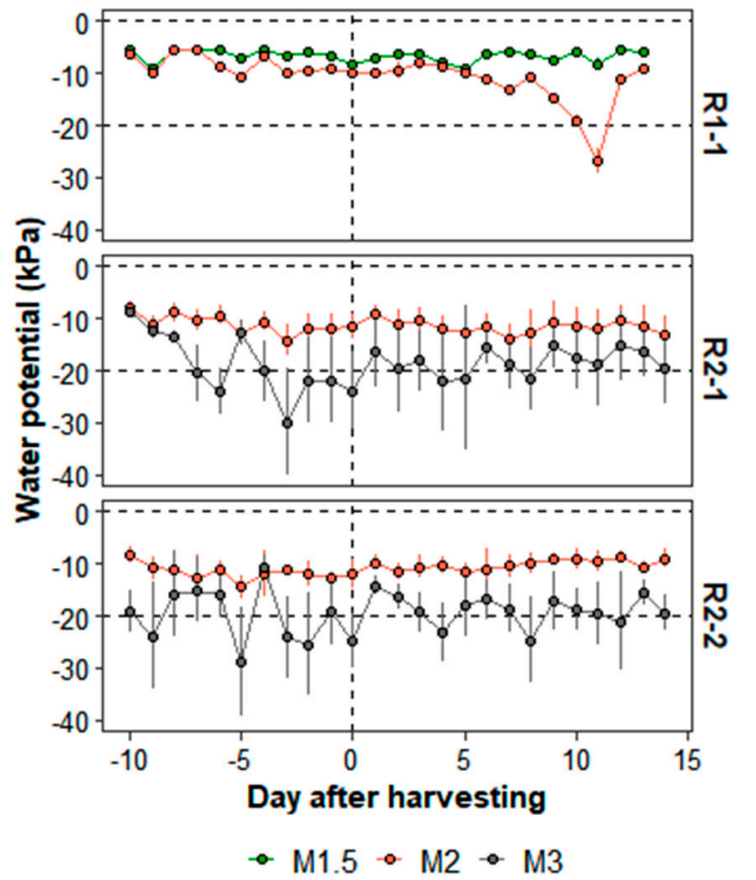

(b)

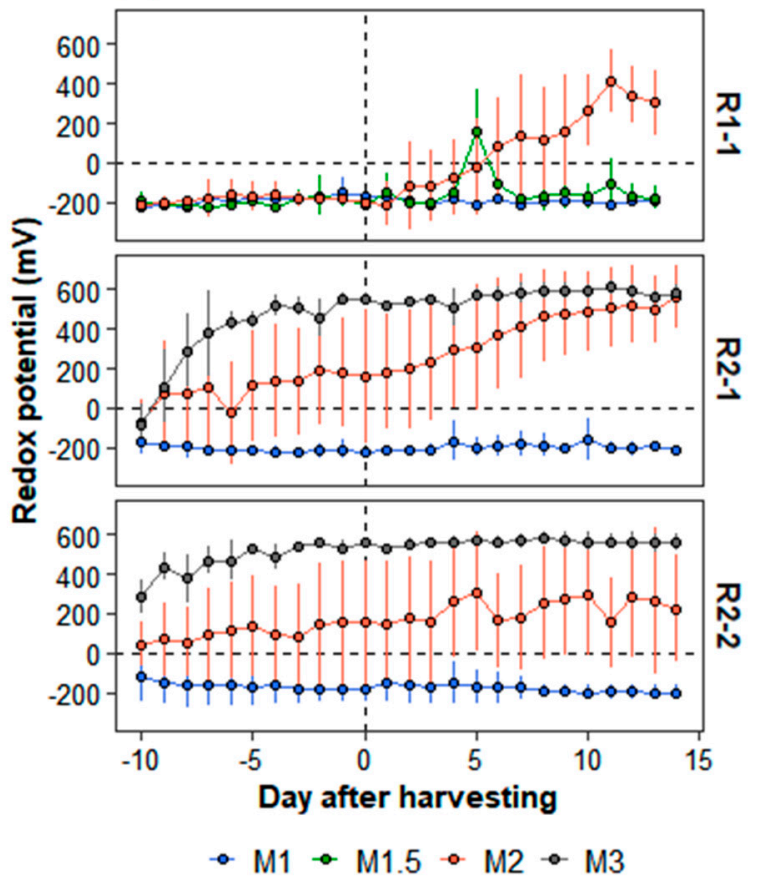

Figure 1. Changes in (a) soil water potential and (b) redox potential in selected tanks under different moisture regimes before and after harvest of the main crop. R1-1, R2-1, and R2-2 represent first ratoons of the first main crop and first and second ratoons of the second main crop, respectively. M1, M2, and M3 represent the saturated, humid, and dry soil moisture regimes, respectively. M1.5 is between M1 and M2. Data represent the mean \pm standard deviation. Sample size of (a) $n=2$ for R1-1, $n=8$ for R2-1 and R2-2, (b) $n=9$ for all ratoons. Dashed horizontal lines indicate 0 and $-20 \mathrm{kPa}$ for (a) and $0 \mathrm{mV}$ for (b); vertical lines represent the day of harvest.

\subsection{Effect of Cutting and Soil Moisture Regime on Regeneration Rate}

For the regeneration rate of plant height shown in Figure 2a, the changes in regeneration rate of each ratoon showed different trends. In R1-1, the regeneration rate increased gradually and reached 1 around 60 days after cutting. In R2-1, the rate hardly increased after 30 days, at up to approximately 0.6. In R2-2, the rate increased rapidly and exceeded 1 at around 30 days. The differences between cutting and moisture regimes on the initial and final regeneration rate of plant height were inconsistent. A significant effect on cutting was observed only at the initial rate of R2-1 $(F 1,18=9.40, p<0.01)$, and a significant effect on moisture was detected in the final rate of R1-1 $(F 2,18=4.24, p<0.05)$ and the initial rate of $\mathrm{R} 2-2(F 2,18=4.38, p<0.05)$.

For the regeneration rate of tillers shown in Figure $2 b$, the trend of changes in ratoons was completely different. In R1-1, the initial rate was higher than that of the other ratoon treatments, reaching 1 only at 7 days, and the number of tillers was maximized at 25-30 days after harvest of the main crop. In R2-1, the initial rate was low, but increased significantly until harvest and finally approached 2. In R2-2, with the exception of M3, which was slightly higher than the others, low rates of around 0.7 remained until harvesting of the ratoons. There was a trend of regeneration rate with regard to moisture regimes, in which the rate of the M3 regime was slightly higher than that of M1 or M2. However, no significant effects of cutting or moisture regimes on the initial or final regeneration rate were observed for all crops. 
(a)

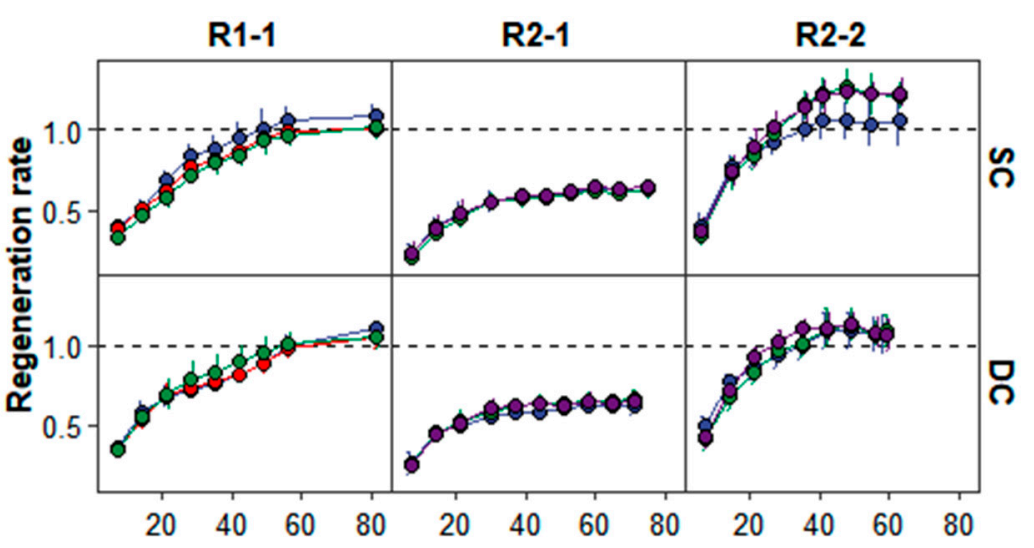

(b)

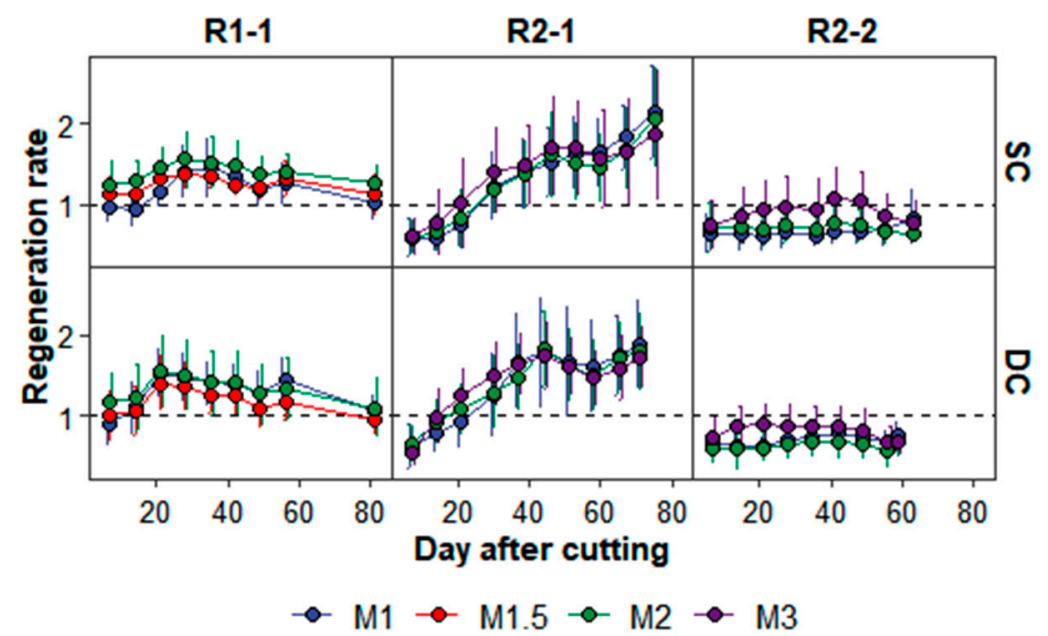

Figure 2. Changes in regeneration rate of (a) plant height and (b) tillers for each regime and ratoon crop. R1-1, R2-1, and R2-1 represent the first ratoon of the first main crop, first ratoon of the second main crop, and second ratoon of the second main crop, respectively. DC and SC indicate double and single cuttings, respectively. M1, M2, and M3 represent saturated, humid, and dry soil moisture conditions, respectively. Data are mean \pm standard error $(n=16,4$ hills $\times 4$ replications).

\subsection{Effect of Cutting and Soil Moisture Regime on Yield Components, Grain Yield, and Harvest Index}

Figure 3 shows the yield components, grain yield, and harvest index of the ratoons for each regimes. We statistically analyzed the effects of cutting and moisture regimes in each ratoon crop, as shown in Table 2. Further details to compare the differences between each treatment can be found in the Appendix A Table A1.

For the cutting regime, significant results were detected in the number of panicles for R1-1, 1000-grain weight for R1-1 and R2-2, and grain yield for R2-2, but all of these were negative effects of DC, and were statistically lower than those of SC. For the moisture regimes, significant effects on filled grain rate and grain yield for all ratoon crops were observed. The filled grain rate and grain yield tended to increase as soil moisture decreased. The M3 regime, which showed an average soil moisture potential of $-19 \mathrm{kPa}$ after harvest of the main crop, had the highest grain yield. This result differed from that of the SALIBU system, which recommends a field capacity level of approximately $-3 \mathrm{kPa}$. In contrast, M1, the saturated regime under continuously flooded conditions, had the lowest yield; approximately $60 \%$ that of M3 in R2-1 and R2-2. 
(a)

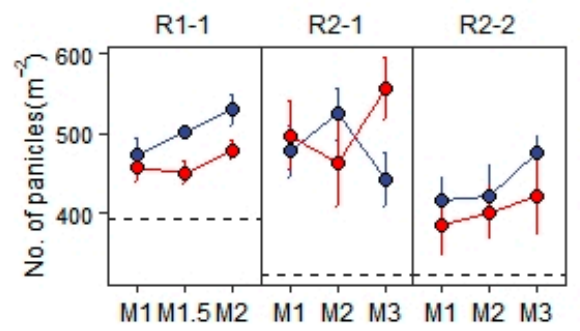

(c)

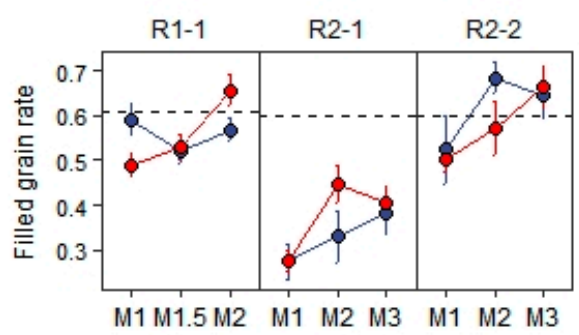

(e)

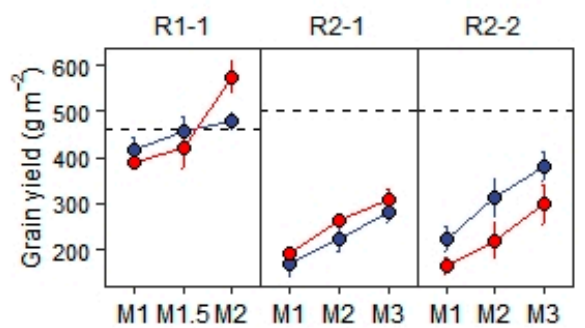

(b)

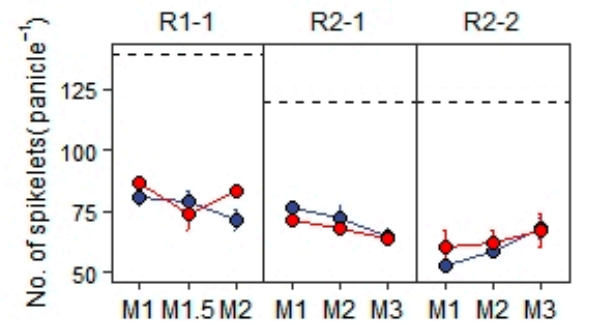

(d)

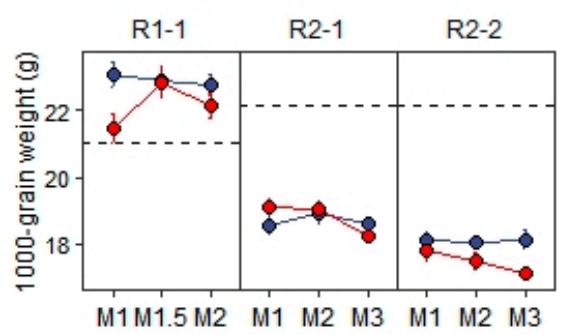

(f)

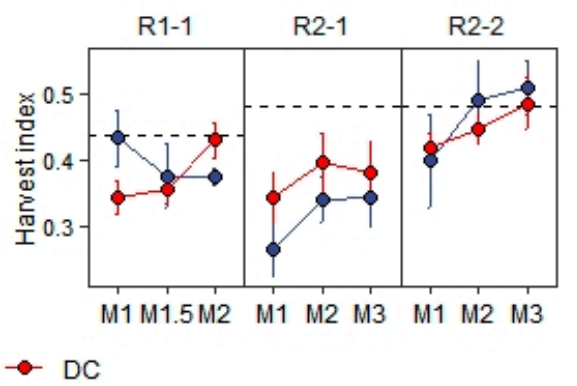

Figure 3. Comparison of differences in cutting and soil moisture regimes on yield components (a-d), grain yield (e), and harvest index (f) of each ratoon. Horizontal dashed lines indicate the mean value of the main crop for each ratoon $(n=24)$. R1-1, R2-1, and R2-1 represent the first ratoon of the first main crop, first ratoon of the second main crop, and second ratoon of the second main crop, respectively. M1, M2, and M3 represent saturated, humid, and dry soil moisture regimes, respectively. M1.5 was between the M1 and M2 levels. SC and DC represent single- and double-cutting regimes, respectively. Values for the ratoons represent the mean \pm standard error of each treatment $(n=4)$.

Table 2. $F$ values in analysis of variance (ANOVA) for comparison of yield components, grain yield, and harvest index of each ratoon crop as affected by the cutting and soil moisture regimes.

\begin{tabular}{|c|c|c|c|c|c|c|c|}
\hline $\begin{array}{l}\text { Ratoon Crop and } \\
\text { Effects }\end{array}$ & Df & $\begin{array}{l}\text { Number of } \\
\text { Panicles }\end{array}$ & $\begin{array}{l}\text { Number of } \\
\text { Spikelets }\end{array}$ & $\begin{array}{c}\text { Filled Grains } \\
\text { Rate }\end{array}$ & $\begin{array}{l}\text { 1000-Grain } \\
\text { Weight }\end{array}$ & $\begin{array}{l}\text { Grain } \\
\text { Yield }\end{array}$ & $\begin{array}{c}\text { Harvest } \\
\text { Index }\end{array}$ \\
\hline \multicolumn{8}{|c|}{ R1-1 } \\
\hline Cutting (C) & 1 & $9.51 * *$ & $1.71 \mathrm{~ns}$ & $0.002 \mathrm{~ns}$ & $5.56^{*}$ & $0.166 \mathrm{~ns}$ & $0.456 \mathrm{~ns}$ \\
\hline Moisture (M) & 2 & $3.47 \mathrm{~ns}$ & $1.87 \mathrm{~ns}$ & $5.14 *$ & $1.27 \mathrm{~ns}$ & $9.43^{* *}$ & $0.632 \mathrm{~ns}$ \\
\hline $\mathrm{C} \times \mathrm{M}$ & 2 & $0.904 \mathrm{~ns}$ & $2.50 \mathrm{~ns}$ & $5.33 *$ & $1.90 \mathrm{~ns}$ & $3.31 \mathrm{~ns}$ & $2.57 \mathrm{~ns}$ \\
\hline \multicolumn{8}{|c|}{$\mathrm{R} 2-1$} \\
\hline Cutting (C) & 1 & $0.547 \mathrm{~ns}$ & $1.74 \mathrm{~ns}$ & $1.81 \mathrm{~ns}$ & $0.334 \mathrm{~ns}$ & $2.80 \mathrm{~ns}$ & $2.79 \mathrm{~ns}$ \\
\hline Moisture (M) & 2 & $0.043 \mathrm{~ns}$ & $5.18^{*}$ & $4.98 *$ & $3.26 \mathrm{~ns}$ & $14.3^{* * *}$ & $1.44 \mathrm{~ns}$ \\
\hline $\mathrm{C} \times \mathrm{M}$ & 2 & $2.42 \mathrm{~ns}$ & $0.26 \mathrm{~ns}$ & $1.08 \mathrm{~ns}$ & $2.17 \mathrm{~ns}$ & $0.079 \mathrm{~ns}$ & $0.113 \mathrm{~ns}$ \\
\hline \multicolumn{8}{|c|}{$\mathrm{R} 2-2$} \\
\hline Cutting (C) & 1 & $1.71 \mathrm{~ns}$ & $0.527 \mathrm{~ns}$ & $0.545 \mathrm{~ns}$ & $9.93^{* *}$ & $7.75^{*}$ & $0.128 \mathrm{~ns}$ \\
\hline Moisture (M) & 2 & $1.11 \mathrm{~ns}$ & $2.35 \mathrm{~ns}$ & $4.10 *$ & $0.963 \mathrm{~ns}$ & $9.72 * *$ & $2.08 \mathrm{~ns}$ \\
\hline $\mathrm{C} \times \mathrm{M}$ & 2 & $0.110 \mathrm{~ns}$ & $0.307 \mathrm{~ns}$ & $0.772 \mathrm{~ns}$ & $1.11 \mathrm{~ns}$ & $0.159 \mathrm{~ns}$ & $0.262 \mathrm{~ns}$ \\
\hline
\end{tabular}

R1-1, R2-1, and R2-2 represent the first ratoon of the first main crop and first and second ratoons of the main crop, respectively. Cutting represents single or double cutting, and moisture indicates saturated, humid, or dry moisture conditions. ${ }^{*}, * *$ and ${ }^{* * *}$ indicate statistical significance at $p<0.05, p<0.01$ and $p<0.001$, respectively. ns: not significant. 


\subsection{Comparison of Yield Performance of the Crops}

In the first trial, the grain yield of R1-1 $\left(457 \mathrm{~g} \mathrm{~m}^{-2}\right)$ reached the same level as that of MC1 $\left(461 \mathrm{~g} \mathrm{~m}^{-2}\right.$ ) (Figure 4a). MC1 was cultivated in the summer, and R1-1 was grown in the monsoon. According to the Department of Agriculture statistics, the national average grain yield of summer rice was $470 \mathrm{~g} \mathrm{~m}^{-2}$ and that of monsoon rice was $370 \mathrm{~g} \mathrm{~m}^{-2}$ in 2017/18. In the second trial, the grain yield of R2-1 $\left(240 \mathrm{~g} \mathrm{~m}^{-2}\right)$ and R2-2 $\left(265 \mathrm{~g} \mathrm{~m}^{-2}\right)$ were significantly reduced to approximately $48 \%$ and $53 \%$ that of MC2 (503 $\mathrm{g} \mathrm{m}^{-2}$ ) (Figure 4a). R2-1 was cultivated in the winter, and R2-2 was grown in the summer. The average minimum temperature was $16^{\circ} \mathrm{C}$ in the winter of 2019-2020. As a physiological response to low temperatures in R2-1, as compared with MC2, plant height and panicle length were decreased by $-35 \%(56 \mathrm{~cm})$ and $-31 \%(16 \mathrm{~cm})$, and excessive tiller occurrence increased by $90 \%\left(30 \mathrm{hill}^{-1}\right)$.
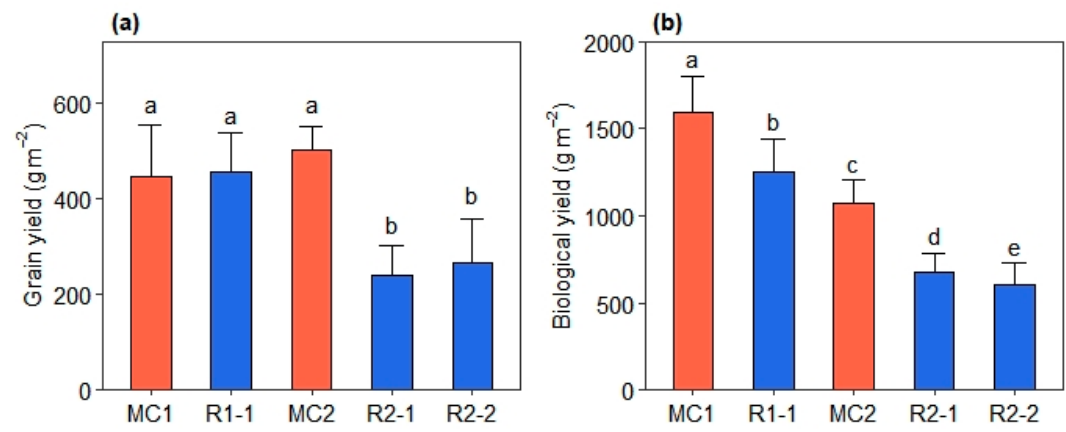

Figure 4. Comparison of grain yield (a) and biological yield (b) are described in order of cropping. Ratoon crops were cultivated under different cutting and moisture regimes. MC1 and MC2 represent the first and second main crop, respectively. R1-1, R2-1, and R2-2 indicate first ratoon of MC1 and first and second ratoons of MC2, respectively. Data are means \pm standard error, sample size $n=24$. Same letters above the bar did not significantly differ at the $5 \%$ level by Tukey's honestly significant difference (HSD) test.

The biological yield of the ratoon was significantly different between the first and the second trial and gradually decreased as the cropping times increased. The highest biological yields were found in MC1 $\left(1593 \mathrm{~g} \mathrm{~m}^{-2}\right)$, and the lowest yields were found in R2-2 $\left(608 \mathrm{~g} \mathrm{~m}^{-2}\right)$.

\section{Discussion}

For ratoon cropping under the SALIBU system in Indonesia, we inferred that excessive suppression by DC of ratooning could affect crop physiological functions and activate regeneration ability, thereby affecting yield performance. However, there was no significant difference between SC and DC in the regeneration rate of tillers in any of the ratoons, and a positive effect of DC on grain yield was not observed. In contrast to our hypothesis, the grain yield of R2-2 (second generation of ratoon) under DC was statistically lower than that under SC (Figure 3e and Table 2). In continuous ratoon cropping, DC may have an adverse effect on the growth of regenerated rice. We concluded that DC in the ratooning system, which uses a cutting height of 30-40 cm for harvesting and height of $5 \mathrm{~cm}$ for ratooning, had no effect on the yield performance of the ratoons.

Meanwhile, there were significant differences between moisture regimes with regard to grain yield and filled grains rate in all ratoon crops (Table 2). The grain yield of M3 was significantly increased by $69 \%$ compared with that of M1 in R2-1 and R2-2. Additionally, although a significant effect of moisture regimes on regeneration rate was not observed, there was a trend in the regeneration rate of tillers in which the rate of M3 was slightly higher than that of the M1 regime (Figure 2b). The dried soil moisture conditions, which had a soil water potential of $-19 \mathrm{kPa}$ and redox potential of $550 \mathrm{mV}$ for the initial growth stage of the ratoons, may have developed root growth and resulted in improved nutrient absorption from the soil; that is, the number of tillers, filled grains rate, and grain yield were improved. In a study on water management by the alternate wetting and drying of irrigated rice, 
Zhang et al. [31] achieved similar results, in which soil moisture conditions with an upper limit of $-15 \mathrm{kPa}$ at depth of $15 \mathrm{~cm}$ contributed to an increased grain yield and root growth in rice. Therefore, soil oxidation conditions during the initial growth stage of the ratoon might contribute to new root growth and could enhance the yield performance. In other words, the yield performance of ratoon crops should be influenced by the drainage condition of the field and the amount of rainfall at the harvest time of the main crop. Considering the low yield of M1 saturated conditions (Figure 3e), ratoon cropping might not be suitable for wetlands or main crop harvest times that overlap with the rainy season. Bukittingi, West Sumatra, Indonesia, where ratoon cropping by the SALIBU system has been practiced, is located in high hills at an elevation of approximately $900 \mathrm{~m}$ with an average temperature of $22{ }^{\circ} \mathrm{C}$ and low temperature of $21^{\circ} \mathrm{C}$ [32]. Lower temperatures extend the grain maturity period and promote the process of grain filling [33]. Therefore, favorable cultivation conditions in drainable fields and temperate conditions with a winterless but not very hot climate may enable high-yielding perennial rice cropping.

Moreover, the comparison of the yield performance of the crops revealed that the grain yield of R1-1 was equivalent to that of the main crop (MC1) (Figure 4a). We found that dry soil conditions before and after harvesting are important to enhance yield performance in ratoon cropping. However, factors in the increased yield of R1-1 included not only the effect of moisture conditions, but also other essential factors, otherwise due to the experiment condition of small concrete tanks. Regarding the experiment conditions, the concrete tank may also have had a negative effect on the yield performance of the ratoon crop because the space for the rhizosphere of the plants is quite limited. Under such a condition, the existing fertility decreases with the progress of the number of cropping times despite application of the same amount of fertilizer. This can result in decreased biological yield with the progress of the number of cropping times (Figure $4 \mathrm{~b}$ ). Therefore, it has been suggested that one of the factors affecting the yield increases in R1-1 is the source ability of the main crop and climate conditions. The nutrients and carbohydrates stored in rice straw are positively related to the ratooning ability of rice [29,34]. MC1 showed the highest biological yield and R1-1 had the highest initial tiller regeneration rate (Figures $4 b$ and $2 b$ ), so the amount of nutrients in the stubble of $M C 1$ affected the regeneration ability and resulted in a yield increase in the ratoons. Additionally, R1-1 was cultivated during the monsoon season, without low- and high-temperature stress. High temperatures reduce radiation use efficiency and result in yield reduction [35]. The climate of Bukittingi, West Sumatra also does not have a hot season. On the other hand, the grain yield of R2-1 and R2-2 in the second trial was significantly reduced to approximately $50 \%$ of that of MC2 (Figure 4a). The reduction yield of R2-1 and R2-2 also resulted in a reduction in sink-source attributed to the excessive tillering with shorter leaves, stems, and panicle length caused by cold stress in R2-1. Cold-induced stress in rice occurs when the temperature falls below $17^{\circ} \mathrm{C}$, causing poor stand establishment and a reduction in yield [36,37]. Therefore, further studies on ratoon cropping should focus on the establishment of the main crop while considering climate conditions.

\section{Conclusions}

Our study showed that cutting regime and interaction between cutting and moisture regimes had no positive effect on the grain yield and regeneration rate of ratoons. We concluded that the double cutting of ratooning rice is not an effective technology. Moreover, we showed that the soil moisture regimes before and after harvesting significantly affected the grain yield of the ratoons. The ratoon crop under the M3 regime, which had an average water potential of $-19 \mathrm{kPa}$ and redox potential of $550 \mathrm{mV}$, was significantly increased by $69 \%$ compared with that under saturated conditions in the M1 regime. Our data suggest that soil oxidation conditions during the initial growth period of the ratoon are important for improving yield performance. Lastly, further studies to clarify the high-yield performance of the SALIBU system are indispensable to generate reliable recommendations to farmers.

Author Contributions: Conceptualization, S.S., K.M.H. and K.Y.; methodology, S.S. and K.Y.; software, S.S.; validation, S.S., T.M.C.; investigation, S.S. and T.M.C.; resources, K.M.H.; data curation, T.M.C.; formal analysis, 
T.M.C.; writing—original draft preparation, S.S.; writing—review and editing, S.S.; visualization, S.S.; supervision, K.M.H. and K.Y.; project administration, T.M.C. and K.M.H.; funding acquisition, S.S. and K.Y. All authors have read and agreed to the published version of the manuscript.

Funding: This study was supported by the Japan International Research Center for Agricultural Sciences Research (project on climate change measures in agricultural systems) and was funded by JSPS KAKENHI (No. 19H05541).

Acknowledgments: The authors wish to express their gratitude to Naing Kyi Win, Department of Agricultural Research, Ministry of Agriculture, Livestock, and Irrigation, Myanmar, and their staff for generous assistance in field observations.

Conflicts of Interest: The authors declare no conflict of interest.

\section{Appendix A}

Table A1. Mean comparison for the plant height, no. tiller, yield components and yield, and harvest index of each crop.

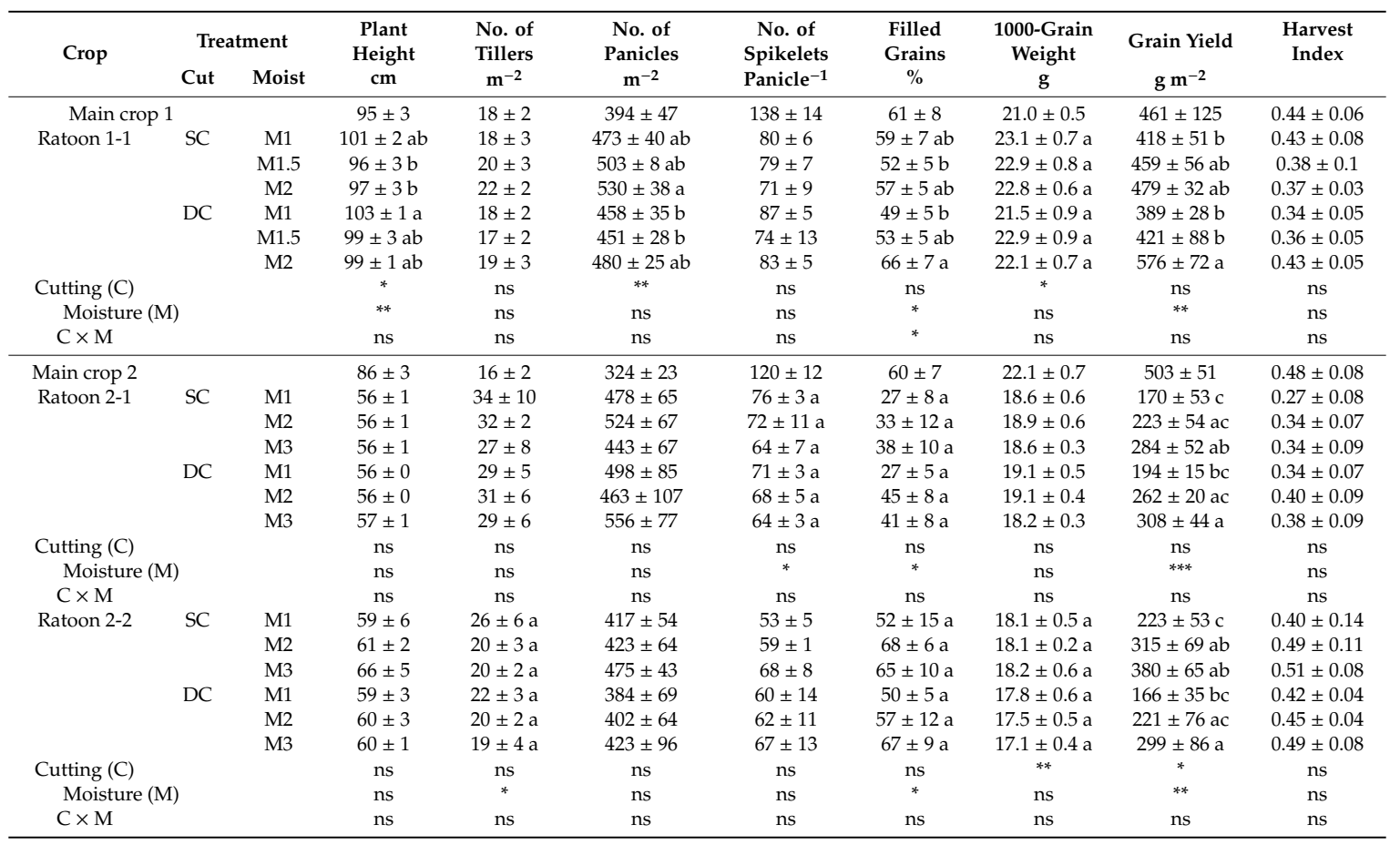

SC and DC indicate single and double cutting. M1, M2 and M3 represent saturated, humid and dry soil moisture regime, respectively. M1.5 is between M1 and M2. Data present the means \pm standard deviation. Sample size is $n=$ 24 for main crop, and $n=4$ for ratoon crop. ${ }^{*}, * *, * * *$ indicate statistical significance at $p<0.05, p<0.01, p<0.001$, respectively. ns: not significant. Values within a column with the same letter for treatments are not significantly different at the $p=0.05$ level by Tukey's HSD test.

\section{References}

1. Mengel, D.B.; Wilson, E.F. Water management and nitrogen fertilization of ratoon crop rice. Agron. J. 1981, 73, 1008-1010. [CrossRef]

2. Munda, G.C.; Das, A.; Patel, D.P. Evaluation of transplanted and ratoon crop for double cropping of rice (Oryza sativa L.) under organic input management in mid altitude sub-tropical Meghalaya. Curr. Sci. 2009, $96,1620-1627$.

3. Liang, Y.; Zhang, Q.; Zhou, J.; Li, Y.; Tan, C.; Huang, H. Effects of different cultivation patterns on rice quality and economic efficiency. Acta Agric. Boreali Sin. 2016, 31, 265-269, (In Chinese with English Abstract).

4. Sen, L.T.H.; Bond, J. Agricultural adaptation to flood in lowland rice production areas of central Vietnam: Understanding the 'regenerated rice' ratoon system. Clim. Dev. 2017, 9, 274-285. [CrossRef]

5. Santos, A.B.; Fageria, N.K.; Prabhu, A.S. Rice ratooning management practices for higher yields. Commun. Soil. Sci. Plant Anal. 2003, 34, 881-918. [CrossRef] 
6. Faruq, G.; Taha, R.M.; Prodhan, Z.H. Rice ratoon crop: A sustainable rice production system for tropical hill agriculture. Sustainability 2014, 6, 5785-5800. [CrossRef]

7. Erdiman; Nieldalina; Misran, M.Y.; Ekamirnia. Salibu Technology Development in Lowland Rice in Three Agroecosystem Zones (AEZ) in West Sumatra; 2014 Assessment Report; BPTP: West Sumatra, Indonesia, 2014. (In Indonesia)

8. Fitri, R.; Erdiman; Kusnadi, N.; Yamaoka, K. SALIBU technology in Indonesia: An alternative for efficient use of agricultural resources to achieve sustainable food security. Paddy Water Environ. 2019, 17, 403-410. [CrossRef]

9. Yamaoka, K.; Khin, M.H.; Erdiman; Fitri, R. Increasing water productivity through applying tropical perennial rice cropping system (SALIBU technology) in CDZ, Myanmar. In Proceeding of the 23rd Congress on Irrigation and Drainage, Mexico City, Mexico, 8-14 October 2017; pp. 1-15.

10. Pasaribu, P.O.; Triadiati; Anas, I. Rice ratooning using the Salibu system and the system of rice intensification method influenced by physiological traits. Pertanika J. Trop. Agric. Sci. 2018, 41, 637-654.

11. Bahar, F.A.; De Datta, S.K. Prospects of increasing tropical rice production through ratooning. Agron. J. 1977, 69, 536-540. [CrossRef]

12. Nakano, H.; Morita, S.; Kitagawa, H.; Takahashi, M. Effects of cutting height and trampling over stubbles of the first crop on dry matter yield in twice harvesting of forage rice. Plant Prod. Sci. 2009, 12, 124-127. [CrossRef]

13. Petroudi, E.R.; Noormohammadi, G.; Mirhadi, M.J.; Madani, H.; Mobasser, H.R. Effects of nitrogen fertilization and rice harvest height on agronomic yield indices of ratoon rice-berseem clover intercropping system. Aust. J. Crop. Sci. 2011, 5, 566-574.

14. Setiawan, A.; Tyasmoro, S.Y.; Nugroho, A. Intermittent irrigation and cutting height on ratoon rice (Oryza sativa L.). Agrivita J. Agric. Sci. 2014, 36, 72-80. [CrossRef]

15. Andrade, W.E.d.B.; Neto, S.A.; de Oliveira, A.B. Utilization of rice ratooning by farmers in Rio de Janeiro State, Brazil. In Rice Ratooning; International Rice Research Institute: Los Baños, Philippines, 1988; pp. 55-60.

16. Jones, D.B. Rice ratoon response to main crop harvest cutting height. Agron. J. 1993, 85, 1139-1142. [CrossRef]

17. Harrel, D.L.; Bond, J.A.; Blanche, S. Evaluation of maincrop stubble height on ratoon rice growth and development. Field Crops Res. 2009, 114, 396-403. [CrossRef]

18. Huossainzade, A.; Azarpour, E.; Doustan, H.Z.; Moraditochaee, M.; Bozorgi, H.P. Management of cutting height and nitrogen fertilizer rates on grain yield and several attributes of ratoon rice (Oryza sativa L.) in Iran. World Appl. Sci. J. 2011, 15, 1089-1094.

19. Beuzelin, J.M.; Meszaros, A.; Way, M.O.; Reagan, T.E. Rice harvest cutting height and ratoon crop effects on late season and over wintering stem borer (Lepidoptera: Crambidae) infestations. Crop Prot. 2012, 34, 47-55. [CrossRef]

20. Daliri, M.S.; Eftekhari, A.; Mobasser, H.R.; Tari, D.B.; Porkalhor, H. Effect of cutting time and cutting height on yield and yield components of ratoon rice (Tarom Langrodi Variety). Asian J. Plant Sci. 2009, 8, 89-91. [CrossRef]

21. Nassiri, M.; Pirdashti, H.; Nejad, T.N. Effect of level and time of nitrogen fertilizer application and cutting height on yield and yield component of rice ratooning. In Proceedings of the Fourth International Iran and Russia Conference, Shahrekord, Iran; 2011; pp. 602-606.

22. Shahri, M.M.; Yazdpour, H.; Soleymani, A.; Shahrajabian, M.H.; Sharifianzadeh, M. Yield and yield components of ratoon crop of rice as influenced by harvesting at different plant height and time. Res. Crop 2012, 13, 408-411.

23. Coale, F.J.; Jones, D.B. Reflood timing for ratoon rice grown on Everglades Histosols. Agron. J. 1994, 86, 478-482. [CrossRef]

24. Ichii, M. The effect of water management on ratoon ability of rice plants. Technol. Bull. Fac. Agric. Kagawa Univ. 1993, 34, 123-128.

25. Bollich, C.N.; Turner, F.T. Commercial ratoon rice production in Texas, USA. In Rice Ratooning; IRRI: Manila, Philippines, 1988; pp. 257-264.

26. Mahadevappa, M.; Yogeesha, H.S. Rice ratooning: Breeding, agronomic practices, and seed production potentials. In Rice Ratooning; International Rice Research Institute: Los Baños, Philippines, 1988; pp. 177-185.

27. Department of Agricultural Planning (DAP), Ministry of Agriculture Livestock and Irrigation. Myanmar Agriculture in Brief; DAP: Naypyitaw, Myanmar, 2016. 
28. Phyo, A.S.; Grunbuhel, C.M.; Williams, L.; Htway, S.S. Does selective mechanization make up for labour shortages in rural Myanmar? IOP Conf. Ser. Earth Environ. Sci. 2019, 338. [CrossRef]

29. Chen, Q.; He, A.; Wang, W.; Peng, S.; Huang, J.; Cui, K.; Nie, L. Comparisons of regeneration rate and yields performance between inbred and hybrid rice cultivars in a direct seeding rice-ratoon rice system in central China. Field Crop Res. 2018, 223, 164-170. [CrossRef]

30. He, A.; Wang, W.; Jiang, G.; Sun, H.; Jiang, M.; Man, J.; Cui, K.; Huang, J.; Peng, S.; Nie, L. Source-sink regulation and its effects on the regeneration ability of ratoon rice. Field Crop Res. 2019, 236, 155-164. [CrossRef]

31. Zhang, H.; Xue, Y.; Wang, Z.; Yang, J.; Zhang, J. An alternate wetting and moderate soil drying regime improves root and shoot growth in rice. Crop Sci. 2009, 49, 2246-2260. [CrossRef]

32. Climate-Data.org: Bukittinggi Climate. Available online: https://en.climate-data.org/asia/indonesia/westsumatra/bukittinggi-32982/ (accessed on 1 June 2020).

33. Funaba, M.; Ishibashi, Y.; Hossain, M.A.; Iwanami, K.; Iwaya-Inoue, M. Influence of low/high temperature on water status in developing and maturing rice grain. Plant Prod. Sci. 2006, 9, 347-354. [CrossRef]

34. Dat, T.V.; Peterson, M.L. Performance of near-isogenic genotypes of rice differing in growth duration. II. Carbohydrate partitioning during grain filling. Crop Sci. 1983, 23, 243-246.

35. Wang, D.; Laza, M.R.C.; Cassman, K.G.; Huang, J.; Nie, L.; Ling, X.; Centeno, G.S.; Cui, K.; Wang, F.; $\mathrm{Li}, \mathrm{Y}$.; et al. Temperature explains the yield difference of double-season rice between tropical and subtropical environments. Field Crops Res. 2016, 198, 303-311. [CrossRef]

36. Sthapit, B.R.; Witcombe, J.R. Inheritance of tolerance to chilling stress in rice during Germination and plumule greening. Crop Sci. 1998, 38, 660-665. [CrossRef]

37. Yoshida, R.; Kanno, A.; Sato, T.; Kameya, T. Cool-temperature-induced chlorosis in rice plants. I. Relationship between the induction and a disturbance of etioplast development. Plant Physiol. 1996, 110, 997-1005. [CrossRef]

Publisher's Note: MDPI stays neutral with regard to jurisdictional claims in published maps and institutional affiliations.

(C) 2020 by the authors. Licensee MDPI, Basel, Switzerland. This article is an open access article distributed under the terms and conditions of the Creative Commons Attribution (CC BY) license (http://creativecommons.org/licenses/by/4.0/). 